\title{
Dreams and Disruption in the Fifties Sitcom
}

Joanne Morreale

The 1950s television sitcom, with its central place in American television and focus on American familial relations in the home, provides a rich site from which to examine the mediated constructions of gender and family relations at a particular social moment. Feminist and historical scholarship has extensively covered this terrain, often with attention to the tensions and contradictions that mark television narratives that appear to present idealized images of the nuclear family. ${ }^{1}$ Although these works provide great insight into ways that ideological fissures mark narratives, there has been little work done on how formal elements such as dream sequences similarly disrupt the coherency of television narratives.

John Thornton Caldwell's Televisuality addresses this issue by noting that dreams and fantasy sequences in early television inserted stylized, cinematic, aesthetic images into otherwise naturalistic television narratives, though he does not consider how these interact with one another within the text. In another case, Cynthia Burkhead's recent Dreams in American Television Narratives uses a Jungian framework to study dream sequences in contemporary television narratives. Because her project is largely the classification of dreams in terms of narrative function, she does not consider the relation of form and content where the visual, highly stylized depiction of dreams contrasts with the "realistic" presentational style that was a hallmark of early domestic family sitcoms.

Here I consider the cultural work of dream sequences in fifties sitcoms and the ways in which the visual excess of dreams in the domestic family sitcom disrupts and destabilizes narrative form and content. I delineate the ways in which dreams and narrative interact to create meaning by referring to Tsvetan Todorov's distinction between generic and cultural verisimilitude. Dreams and fantasy sequences in television sitcoms, marked by aural and visual 
conventions initially established in classical Hollywood film, have generic verisimilitude. These stylized generic conventions, imported to the television domestic sitcom, mark dreams and fantasies as separate from the narrative and also render them intelligible as expressions of a character's subjective desires or fears. But dreams and fantasies are by nature incompatible with cultural verisimilitude... what is perceived as a realistic representation of social reality. Fifties domestic family sitcoms were largely "realistic" depictions of suburban life; their presentational "anti-style" and naturalistic direction, which Caldwell refers to as "zero-degree television,"2 worked to convey cultural verisimilitude. Dreams and fantasies, marked by stylistic excess, intrude upon this otherwise naturalistic presentational style. In so doing, they offer a way to speak the unspoken and undermine the harmonious image of the family offered in the narrative.

I suggest that, just as in early television narratives, film and Hollywood were positioned as threats to both television and the "ordinary" family; on the formal level, the "cinematic" style of dream sequences in domestic family sitcoms challenged their cultural verisimilitude in a way that magnified tensions around gender and the family. Dreams threatened the stability of both sitcom form and narrative content; in contrast to the familiar domesticity of television, they introduced what was unfamiliar and "unhomey," whether in terms of the break from the narrative's verisimilitude or in the representation of desires and fears that were typically excluded from the narrative. They offered a plausible subjective reality that challenged the primacy of the zero-degree narrative. In this way, they undermined the ideology of domestic containment that served as the linchpin for both the postwar period and the situation comedy that centered around the nuclear family. They articulated female dissatisfactions and male anxieties that were just as real as the narratives they disrupted.

Here I consider representative dream sequences from four early television sitcoms: Molly: "Molly's Dreams" (1955); I Married Joan: "Dreams" (1952); The Donna Reed Show: "The Stones Go to Hollywood" (1960); and Father Knows Best: "Betty Earns a Formal" (1956). Though all of these are domestic sitcoms that speak to gender and family relations in the fifties and early sixties, there are variations in their uses of dreams to destabilize narrative form and content. In "Molly's Dreams," there is no visualization of Molly's dreams and thus little break with narrative verisimilitude. Her dreams 
remain subordinate to naturalistic television conventions, and are thus easily dismissed as "not real." In "Dreams," Joan's theatrically staged dreams illustrate her desire for a career and work to support the notion, indicated within the narrative, that Joan is not fully domesticated. In this way, they do not challenge the primacy of the narrative so much as emphasize its tensions. As Patricia Mellencamp writes in her influential 1986 essay "Situation Comedy, Feminism, and Freud," early television comedy was populated by powerful female stars who were "humorous rebels" or "welldressed, wise-cracking dissenters who wanted or had a paid job."3 Although Mellencamp focuses on Gracie Allen and Lucille Ball, Gertrude Berg and Joan Davis similarly fit this model. Both produced their own shows and portrayed characters who rebelled against domestic containment, whether through Berg's role as family matriarch or Davis's attempts to have a career.

Mellencamp adds that as television became an increasingly powerful machine for the domestic containment of women in the fifties, the terrain of the sitcom altered. Typical domestic sitcoms began to feature a middle-class nuclear family living in the suburbs. As was the case in sitcoms such as The Donna Reed Show and Father Knows Best, the housewife became contented and complacent rather than dissatisfied and rebellious. I argue that, as the figure of the housewife became increasingly contained, the cinematic dream became a powerful means to contest the primacy of the narrative and the ideology of domestic containment. In "The Stones Go to Hollywood," Donna's dream contests her narrative representation as a contented housewife and inscribes both the actress and character as a powerful female who resists containment; while in "Betty Earns a Formal," centered on family patriarch Jim Anderson, the dream illustrates male fear of the woman who is no longer contained, whether within the narrative or the home.

\section{Molly: "Molly's Dream"}

Molly was the "domesticated" version of The Goldbergs (1949-56), one of the first successful sitcoms on television. A radio sitcom that migrated to television, The Goldbergs was written by, produced by, and starred Gertrude Berg, depicting her as the Jewish family matriarch, an axial character who typically controlled the narrative, even to the extent that she could break the fourth wall as she leaned out of her kitchen window to get closer to 
viewers and tout the calming effects of Sanka coffee. George Lipsitz notes that sitcoms such as The Goldbergs helped to facilitate the postwar cultural transition from ethnic identities to consumer identities. Not only were sponsors' products naturalized within these programs, but, in order to convey authenticity, "real" problems and dissatisfactions often motivated narratives, though these were typically resolved by the purchase of a product.

The Goldbergs is probably best known because Philip Loeb, who played Molly's husband, was accused of being a communist sympathizer, and both CBS and Berg's sponsor, General Foods, ordered her to fire him. She refused, and production on the then popular program halted for a year and a half. When it returned to the air in 1954, The Goldbergs moved from NBC to the struggling DuMont network. By then, newer sitcoms such as I Love Lucy (195157) and I Married Joan (1952-55), featuring the young, attractive middle-class housewife, had begun to supplant ethnic family sitcoms such as the widely popular Mama (1949-57). When DuMont could not afford Berg's contract and had difficulty securing a sponsor, in an attempt to stay on television she signed a contract with Guild Films, an independent film company that specialized in syndicated television shows. Although The Goldbergs had always been live (only some were preserved on kinescope), and Berg believed that live programs were superior to filmed, she agreed to switch to film so that the program could air in firstrun syndication. Berg also agreed to rename the program Molly, and in so doing, to erase her ethnic identity. ${ }^{5}$ The urban, working-class, ethnic, matriarchal family became upwardly mobile as the Goldbergs were "modernized" by assimilating into the middle class. Molly began in 1955 with the family moving from the Bronx to the New York suburb of Haverford. Although Molly's Uncle David remained with the family - so it did not conform entirely to the nuclear family model-both children attended college, and husband Jake established a bridal gown business as the Goldbergs fulfilled the American Dream. Despite these changes, Molly only lasted one season.

"Molly's Dreams," aired in 1955, was written by Berg. It addresses the resentment felt by women like Molly, transplanted from the city and confined to the suburban home. In an effort to stimulate the economy by bolstering consumption, encouraging home ownership, and repopulating the nation in the postwar period, government, industry, and media coalesced to promote the suburban, 
middle-class, nuclear family ideal now embodied by Molly, Jake, and their children. Jeffrey Sconce writes, "Throughout the 1950s and into the 1960s, television developed a highly codified series of narrative conventions to represent this emerging suburban ideal, constructing a middle class utopia of labor-saving appliances, manicured lawns, and spacious architecture, all designed to showcase the white suburban housewife as the ultimate symbol of material success and domestic bliss." 6 From another vantage, both Mellencamp and Elaine Tyler May refer to the strategic "domestic containment" of women as the corollary of the foreign policy of containment meant to preserve the American way of life against communism. The home became the site where dangerous forces that threatened social stability could be tamed. Yet, May writes,

The home contained not only sex, consumer goods, children, and intimacy, but enormous discontent, especially for women. For many, there was no place else for this discontent to go, so it remained contained in the home.... For these white middle-class couples, viable alternatives to domestic containment were out of reach. The cold war consensus and the pervasive atmosphere of anticommunism made personal experimentation, as well as political resistance, risky endeavors with dim prospects for significant positive results.... With depression and war behind them, and with political and economic institutions fostering the upward mobility of men, the domesticity of women, and suburban home ownership, they were homeward bound. But, as the years went by, they also found themselves bound to the home. 7

The television sitcom, based around the nuclear family and itself situated in the home, became a primary support for the ideology of domestic containment. In her early years on television, Molly Goldberg lived in an apartment building and was engaged with a community of neighbors. However, in "Molly's Dreams," while there is still a loose community of neighborhood women, Molly is confined to the home and domestic chores. She takes no part in public life and is reluctant to even join the PTA. She insists she is happy being a housewife, but then recounts a dream to her neighbor, Mrs. Van Ness, that, despite her protests, suggests otherwise. 
As Mrs. Van Ness leaves to offer advice to another neighbor, she warns Molly, "Most of the women in our neighborhood need therapy; they don't know how unhappy they are." Molly, clearly worried, decides that she will join the PTA. "Maybe I'm not a housefrau," she wonders; her words belie the image as she hangs laundry on the clothesline. Her attempt to follow Mrs. Van Ness's advice appears rewarding. She attends a PTA meeting, after which she arrives home at 1:00 a.m. because the group became engaged in a discussion. As she prepares to leave again the next morning, Molly stops to write down her dream; she appears excited as she reveals to Jake, "A new world is opening up to me." She is referencing her dreams, though his reply speaks instead to her newfound independence: "Hold on to the old one. I like it very much." Molly then relates another dream to Mrs. Van Ness, which is interpreted to mean that she is stifled and wants to express herself through music. Molly takes up the piano, though the narrative makes clear that she has no talent, and thus belittles her quest for fulfillment outside of the family.

In Molly's final dream, she vacuums the carpet and accidentally sucks up her family, but when they scream for help, she puts them in the closet and locks the door. Mrs. Van Ness tells Molly she has a death wish for her family; she hates her husband and sees her children as obstacles. Molly is distraught, telling Uncle David, "I am my dreams and my dreams are me." She becomes even more upset when, in an attempt to smooth daughter Rosalie's hair, she accidentally pulls it and is rebuffed with a sharp, "Do you want to take my head off?" Then, when she tells Jake she has made goulash for dinner, he admonishes her with, "You know what goulash does to me... What do you want to do, poison me? If I die it will be your fault!" He then berates her for forgetting to buy the bicarbonate he will need for his stomach if he eats the goulash. Molly, upset not at the poor way she is treated by her family, but by her fear that her dream is coming true, decides to go for a walk. When Uncle David offers to accompany her, she refuses, protesting, "I'm a woman. I'm mature. I have to overcome my infantilism."

Throughout the episode, Mrs. Van Ness is made to look silly and uninformed, using Freudian psychobabble to diagnose the women in the neighborhood, and the women 
who follow her advice are similarly made to look foolish.

When Molly leaves for her walk, son Sammy, husband Jake, Uncle David, and Mrs. Carey's husband all unite to protest that Mrs. Van Ness has no authority or qualifications to interpret dreams. Notably, Rosalie is absent from this male group, who all decide, "We have to do something about these womenfolks of ours," and ask, "By what right does she pass out interpretations and symbols?" The men solve the problem when Jake invents a dream that Mrs. Van Ness interprets to mean that he wants to kill Molly and marry his bookkeeper. Molly sees through this ruse because, as she proclaims, Jake's bookkeeper is "sixty-eight years old and three times a grandmother," and Mrs. Van Ness's spell is broken. As the episode concludes, Jake tells Molly that he too has dreamed that the vacuum cleaner has sucked her up along with the children, and he asks her what it means. Her answer does the work of recuperation: "It means we should always be together very close... I love you and you love me. And I need a new vacuum cleaner."

Unlike sitcoms that utilize a dream sequence that competes with the realistic narrative, here the subject of the narrative is Molly's dreams, which are never visualized and given a status alongside the diegetic world. Although Molly was filmed, it remained tied to the naturalistic style most typical of the suburban domestic sitcom it aspired to become. Unlike network programs, syndicated programs such as Molly did not have the budget for elaborate dream sequences. More important, Molly, already undergoing a narrative transformation that was all about conforming to the new television landscape, was unlikely to disrupt the verisimilitude of the "ordinary" domestic sitcom through cinematic visual excess. Within the narrative, Molly's dreams express her quite reasonable dissatisfaction with her relegation to the domestic sphere, her lack of a creative outlet, and her poor treatment by her family. Her dreams encourage her to participate in public life and to explore her creativity. Briefly, they give her insight into the fact that she is a mature woman who, as Molly herself observes, has to overcome her infantilism, which is a consequence of her relegation to the home. But the narrative's objective is to discount the significance of her dreams-and dissatisfaction -and to reinstate her as a contented suburban housewife, one whose major unfulfilled desire is for a new vacuum cleaner.

The episode concludes when Molly decides that Mrs. Van Ness is a sham, rendering her interpretations 
meaningless. Throughout, there is no disruption of narrative verisimilitude, no stylistic excess that would displace the primacy of the zero-degree narrative. Its credibility, already at stake in The Goldbergs' transformation to Molly, is not challenged by Molly's dreams. They have no shape, no markers, no existence apart from Molly's words. Though an oppositional reading that focuses on tensions rather than their resolution is possible, Molly's dreams are easily dismissed as the narrative concludes. The matriarch of The Goldbergs is transformed into an emblem of domestic contentment, just as the preferred narrative meaning emerges out of the "truth" of what is seen and said rather than what is "unconscious." At the episode's beginning and end, Molly insists that she loves being a housewife, and the alternative perspective that challenges her words ultimately has no authority.

In other sitcoms-here I will discuss I Married Joan, The Donna Reed Show, and Father Knows Best-tensions were expressed through stylized dream sequences that disrupted the conventions of naturalism and cultural verisimilitude that were the linchpins of domestic containment. The domestic sitcom's perceived realism merged the world outside and inside the home. But sitcoms that imported highly stylized, even surreal film styles and conventions to television through dream sequences contested the primacy of cultural verisimilitude. In contrast to Molly, produced in New York and emblematic of television's roots in the live theatrical tradition, all of these latter programs were made in Hollywood, and thus marked the uneasy partnership of film and television in the fifties and the importation of cinematic values to television. In "Dreams," "The Stones Go to Hollywood," and "Betty Earns a Formal," dreams depart from the naturalistic conventions of the domestic sitcom and give shape to the tensions implied by or repressed from the narrative. In this way, their visual and narrative excess undermines both the form and content of the domestic sitcom.

\section{Married Joan: "Dreams"}

An early example of the visual dream sequence as a way to express unfulfilled desires occurred in the "Dreams" episode of I Married Joan, airing in 1952 and starring comedienne Joan Davis. I Married Joan was developed in response to the success of I Love Lucy, which debuted in 1951 and was the top-rated situation comedy at the time. NBC was eager to emulate Lucy's success by airing a 
domestic sitcom that starred a woman who could do Lucystyle physical comedy. Davis was a vaudeville, film, and radio comedienne who, like Lucille Ball, was comfortable with physical slapstick humor. By 1952, Davis decided to follow trends and move to filmed television, and to base production in Hollywood. She secured a sponsorship deal with General Electric and produced I Married Joan for NBC. Like Berg, Ball, and Reed, Davis maintained creative control over her programs; she headed her own production company, Joan Davis Enterprises, and was executive producer of the series. (A few episodes were contracted out to Volcano Productions, including "Dreams.")

The show was filmed on a soundstage at Hollywood Center Studios, which accounts for the limited number of sets. In accord with the bland, zero-degree shooting style that characterized telefilms at this time, I Married Joan largely consists of a static camera and a pattern of medium to medium-close-up shots. Its premise is that Joan has given up aspirations for stardom in order to become a housewife, though she frequently schemes to find a career. In typical episodes, Joan's escapades exasperate her husband, who ultimately forgives her in the end. Like Lucy, Joan has not yet become the docile housewife typical of sitcoms consisting of nuclear families set in the suburbs. She is feisty, not naturalized in her household duties, and her lack of domestic skills often poses problems for her husband. Yet, like Lucy Ricardo, Joan is narratively consigned to the housewife role, and the humor comes from her attempts to escape domestic confinement.

"Dreams" follows this model as Joan fantasizes that she has a powerful and successful career. In the narrative, Joan reunites with her three single friends from high school, and is excited to tell them that she is married to a judge. However, her friends have become a famous athlete, a makeup designer, and an advisor to the president. When they ask Joan what she has been doing, she is abashed and stutters, "I make great meatballs." The scene cuts to Joan in a conversation with her husband Bradley, who she asks, "What about an identity of my own?" She adds, "If it weren't for you marrying me, I might have been a somebody too." As Joan imagines who she might have become, her internal thoughts are expressed in a voice-over, already a departure from narrative verisimilitude. Her dream is marked by the generic conventions associated with the dream sequence: a wavy dissolve, choir music, and a shift in setting. Her fantasy becomes a surrealist vision (though surrealism on a 
budget). Joan wears a suit and tie and sits at a desk that appears to be elevated. It is a disguised version of the same desk used in shots of Bradley at work. The area around her is black, decorated only by giant perfume bottles hanging at odd angles.

I Married Joan

Video: I Married Joan

As Joan revels in her success as an unmarried entrepreneur, Bradley bursts into her dream, complaining that she has starched his shirt collar against his wishes. Joan tries to hold onto her fantasies, and claims that she is Lady Joan, who doesn't have to worry about husbands or washing shirts. Yet, when she asks Brewster and her staff to remove Bradley, it is they who suddenly disappear. Joan touches Bradley's nose, feels that it is real, and is distraught. A wavy dissolve indicates the end of the dream, and Joan and Bradley are once again seated next to one another in the living room. "What about the starch in this shirt?" he persists. In a resigned, less authoritative voice than she exhibited as an executive, Joan answers, "All right, I'Il take care of it."

Joan fantasizes about power, escape from drudgery, being single (and having a very long cigarette holder as signifier of masculine power). Although the dream sequence is "bracketed" from reality by the wavy dissolves, music, and distinct visual style, the figure of Bradley connects the twoon the level of both form and content, Bradley disrupts Joan's dreams. The dream, with its stark setting and surreal imagery that differentiates it from real life, highlights the disparity between the powerful executive Joan and the housewife who washes the starch out of her husband's shirt. But the dream articulates Joan's very real dissatisfaction, calling into question the primacy of the narrative where she acquiesces to Bradley's demands.

As she begins to wash his shirt, Joan fantasizes that "with proper breaks," she could have been a great swimmer like her friend. In the ensuing dream, she is swimming across the ocean to England. There is no attempt at realistic depiction here, with the set a mere gesture toward the visual appearance of actual waves in the water. Bradley emerges from a barrel and chastises her, "Joan, what in the world are you doing? This salad dressing tastes terrible and the dinner isn't half ready. Don't you realize a husband has certain rights..." She again touches his nose; her dream is again 
interrupted as she realizes that he is real.

Back in the kitchen, Bradley complains again about

the salad dressing, and Joan simply agrees to fix it. As she works, he admonishes her to have concern for his feelings and be a little diplomatic; this cues her final dream, in which she has become a diplomat who advises the French president. This set is also stark and removed from reality by a black backdrop, with only Joan and the president seated again at the desk. Their conversation is interrupted by the message that there is a "special courier with new orders." Bradley appears and demands, "And your orders are to come home. The salad dressing is okay but what about the rest of the dinner?" Again this brings Joan back to the kitchen. Like Molly Goldberg, Joan's dreams lead her to a momentary self-realization, and she reacts by informing Bradley that she never should have gotten married. The narrative depicts her as little more than a domestic servant, with Bradley haranguing her about dinner, obsessing over salad dressing, arguing that having housework done is a husband's right, and even "ordering" her back into the home. In this context, Joan's dreams seem more reasonable than the domestic containment that the narrative attempts to reassert as the natural social order.

The episode concludes when Bradley agrees to Joan's request to go and make her mark on the world, but he adds, "But before you start out on your new venture, you have to be a good little housewife for one more night and fix a nice dinner because we are having company." The company turns out to be Joan's three successful friends. As they converse with Bradley, Joan emerges from the kitchen and announces that Bradley has "released" her from being a housewife. She tosses her apron and proclaims, "No more drudgery for me!" Her friends then complain of the drudgery involved in their careers, and when Joan asks them what they really want, one replies, "A man to take care of me." The others agree and all begin sobbing. Joan begins sobbing too, but then realizes, "Wait a minute, I have a man." As she leans over Bradley and pins him down in an extended embrace, the studio audience applauds. In the program's epilogue, Bradley thanks the women for coming when he called and for their fine acting performances. They joke that they were not acting and kiss him on the cheek, at which point Joan intervenes and shoos them out the door.

The audience applause suggests that Joan's reinstatement in the family is the satisfactory resolution to the narrative, though it also suggests a need to underscore 
this point. But just as the dream sequences free the narrative from mundane household scenes, they free Joan from cooking dinner and washing shirts. The dreams escape the confinement of the narrative, and the pat ending does not dispel the tensions they illuminate.

\section{The Donna Reed Show: "The Stones Go to Hollywood"}

The Donna Reed Show (1958-66) and Father Knows Best (1954-60) were more emblematic of Hollywood cinematic style than I Married Joan. Both were produced by Screen Gems, the television arm of Columbia Pictures, and filmed on Blondie Street, a façade of suburban houses located on the Columbia lot. (In the case of The Donna Reed Show, Screen Gems and Donna Reed's production company, Todon Productions, were co-producers.) Because both programs were associated with Columbia, they also had access to film sets and locations from a number of different cinematic genres, which facilitated the use of dream sequences. Thus while Joan's dreams are visual, they do not have the cinematic production values of these sitcoms. Moreover, both of these sitcoms were far more representative of the ideology of domestic containment than either Molly or I Married Joan. Both feature middle-class nuclear families raising children in nondescript suburban towns, with a breadwinner father, and mother as an attractive, seemingly contented housewife. Both Donna Stone and Margaret Anderson are more modern than the old-fashioned, matronly Molly Goldberg and less madcap than Joan Davis, though tensions around female independence and power continue to mark the narratives.

The Donna Reed Show was immersed in Hollywood film practices because its star was also a producer, and thus it was more inclined to visual experimentation than Father Knows Best. ${ }^{8}$ Reed had been a Hollywood film actress who, along with her husband Tony Owen, decided to shift to television as her film career began to wane. They formed their own production company, Todon (an anagram of both their names, modeled after Desilu), though they remained connected to Columbia Pictures through Screen Gems. One episode in particular, "The Stones Go to Hollywood," clearly marks The Donna Reed Show at the interstices of film and television, and pits the domestic world of television against the unhomey world of film. The self-reflexive episode contrasts the "ordinary" housewife and the "excessive" Hollywood star, and seemingly suggests that the two are incompatible. But because the episode plays with the 
boundaries between film and television, and the real and the fictional, the narrative attempt to affirm domesticity is more difficult to attain.

Cinematic excess spills into this "special" episode, as the Stone family leaves its familiar domestic setting to visit Hollywood. The episode opens conventionally, as Donna sews at the table and helps son Jeff with his Civil War homework. He plays with a paper airplane and complains. She is the ideal mother who remains patient, though she reminds him that Abraham Lincoln had to do arithmetic on the back of a shovel and walk miles to school. She denies her own irritation and defers her authority by warning Jeff, "Your father is going to be very unhappy if you get another $\mathrm{C}$ in history." In the midst of this domestic scene, the "cinematic" intervenes as there is a cut to daughter Mary, who promotes Pepe, a film being made at the time by director George Sidney in which Reed had a cameo role. "It's a picture you shouldn't miss," Mary proclaims to both her friend on the phone and the audience at home, as she describes the plot. Husband Alex then arrives home, and invites the family to join him for a meeting in Los Angeles. Cinematic conventions to indicate a change of scene quickly replace those of the domestic sitcom. In a brief montage sequence, Jeff lets his paper airplane fly; this is followed by a cut to stock footage of a plane landing, then the exterior of a hotel bearing a "Hollywood" sign. The Stone family is suddenly gazing at the Hollywood Hills. They are removed from the staged suburban setting of the sitcom, and viewers see the typically invisible "real" location of the show. But throughout the episode, the ordinary television family is differentiated from, and subordinate to, the glamorous world of Hollywood.

The family learns that Alex is working with the film director George Sidney, and pressure him to wrangle an invitation to visit a movie studio. They are obsessed with glimpsing film stars, but there is no reference to television stars. As they arrive on the lot where The Donna Reed Show is filmed, it is populated not by conventional television actors, but by an array of spectacular costumed characters: a knight, women wearing boas, a clown, and a man dressed as Abraham Lincoln who holds a shovel. The plainly dressed Stone family, however, occupies center frame as they march through the lot. Despite the fact that The Donna Reed Show actors are the stars "at home" on the set, their characters gaze in awe at the excessively stylized cohort that surrounds them. Sidney then takes them to watch him shoot a scene 
from Pepe. A surreal dance is inserted into the episode, as two men wearing oversized sombreros perform in front of a life-sized telephone (an actual scene from the not yet released film). Here cinematic excess, typically bracketed in dream sequences, has spilled into the narrative.

Sidney then offers the Stone family a small role in his film, where all they have to do is "act natural"—real actors play fictional characters who are asked to perform as "real" people. Later that night, Alex confesses to Donna that he is nervous about acting on camera. The camera lingers on her face, dramatically lit and shot in close-up, as Donna Reed/Donna Stone replies, "Don't be silly. There's nothing to it." Donna Stone does, however, begin to feel tense, which prompts her to read a movie magazine as she tries to fall asleep. Again, she is shot in close up and in center frame as she muses to Alex, "It's surprising how many movie stars have children. I never think of them as having private lives." The framing deliberately confuses Donna Reed, the real-life movie actress who was the mother of four children, and Donna Stone, the fictional housewife who dreams of becoming a star.

Donna's dream is signaled by an extremely long take of her reclining head, in profile with eyes closed. The background is in soft focus, and the camera moves in to a close-up as eerie music indicates a disturbing shift in tone. The close-up of the character falling asleep in bed, along with the music and wavy dissolve signal the cinematic dream sequence, as does the laugh track that accompanies the transition. The subsequent dream becomes a parody of cinematic excess, represented by the narcissistic movie star with adoring fans, no apparent husband, and a distant connection to her children. It contrasts the unmotherly but glamorous Hollywood star with the domesticated, asexual television mother. Cinematic excess is counterposed to the mundane suburban world of Donna Stone and the television sitcom.

The dream can be read as an expression of Donna Reed's wish to escape the constraints of the domestic sitcom, as well as Donna Stone's fantasy of life without children who complain and quibble. Throughout her film career, Reed was cast as a wholesome "good girl," though she wanted more complex roles (which she got only once, playing a kind-hearted prostitute in From Here to Eternity), and she never quite achieved A-list status. This dream sequence allows her to parody the vampish Hollywood diva (specifically, Bette Davis). She is allowed the sexuality that 
is repressed in the domestic sitcom as well as the fame and adulation that is accorded the Hollywood film star.

\section{The Donna Reed Show \\ Video: The Donna Reed Show}

Most important, she has a distant relation to her children, whose names she cannot even remember. The sequence, though a parody of excess, gives Donna a certain power at the expense of her maternal role. Jeff appears dressed as Abraham Lincoln while Mary has a huge bow in her hair like the costumed extras from the set. Jeff's appearance references both the opening scene of the episode and the actor observed on the studio lot: he carries a shovel on which he has done some addition problems incorrectly. This time, Donna is not patient, but sharp: "How do you expect to become president if you can't do your sums!" As the children begin to argue, rather than tolerate them as Donna Stone would do, she briskly tells them to run along and shows them the door. In lieu of spending time with them, she offers them an autographed picture (a publicity photo of the real Donna Reed). After they leave, she asks her secretary, "Why can't I be like other mothers and spend time with my children?" When her secretary answers, "That's the price you pay for being a star," Donna asserts, "Well then it's not worth it. I want to be just simple Donna Stone, secure in the love of my husband and children." But she is quickly diverted as she pats her cheek and says, "Just tell the photographers to photograph me only on this side" (another reference to the real Reed, who only wanted to be photographed from the left).

Sidney enters, and tells Donna that her latest film has been very successful. Although her initial response is that she has no head for figures, she quickly makes apparent that she has complete command of the numbers. He then offers her another script, supposedly written by Hemingway. She declines and declares, "I am going to be a simple housewife and mother." Sidney convinces her to just look at it—she barely skims the pages and immediately agrees to do it. It is "movie star" Donna's desire to be a wife and mother that is the pretense of this dream. Despite her assertions to the contrary, her desire is for stardom, not motherhood. The dream sequence positions Hollywood as a threat to domesticity, and cinematic excess as a threat to the narrative's cultural verisimilitude. The dream is given added weight through its blurring of Donna Reed and Donna Stone. 
A wavy dissolve, this time accompanied by the strum of a harp and then the show's theme music, brings Donna Stone back to her bed. She is shot in extreme close-up as she awakens, and this time the camera zooms out rather than in to locate her back in a familiar domestic space. She smiles in relief as she realizes where she is, and light, upbeat music rises to a crescendo as the screen fades to black. In the epilogue, the family prepares nervously for their film roles, and all admit that they do not want to be in the movie. They are released from their responsibility when Sidney is unexpectedly called away. His secretary rewards them by introducing them to a star, who turns out to be Lassie. The Stone family, no longer drawn to the cinematic, is perfectly content to meet a television star, even a canine, and audience applause confirms the "rightness" of this ending.

The dream sequence in The Donna Reed Show marks the moment where television becomes cinematic; and the cinematic sequences express all of the tensions that television represses, providing a kind of freedom, allowing Donna Stone a complexity and means to break free of her otherwise constrained representation. Throughout "The Stones Go to Hollywood," the cinematic-which confounds the distinction between television and cinema, Donna Reed and Donna Stone, and the real and the fictional-calls the narrative's verisimilitude into question.

\section{Father Knows Best: "Betty Earns a Formal"}

While dreams often express otherwise repressed female desires, males may have nightmares that express fear of female power and sexuality. One such case occurs in the "Betty Earns a Formal" episode of Father Knows Best, airing in 1956. In domestic sitcoms such as Father Knows Best, plots often focus on the father-child relationship while the mother is marginalized (Liebman); thus in this episode, the patriarch Jim's dilemma prompts a dream. Here, daughter Betty asks her father to pay for a dress for the Cinderella Ball. Jim refuses on the grounds that it is too expensive, telling her that if she wants the dress, she will have to go out and earn the money herself. Betty, desperate to impress her date, angrily retorts that she will get a job on afternoons and weekends to pay for it. But Jim becomes increasingly guilty and anxious. His younger daughter Kathy asks if he is a "tightwad," thus implying that he is not able to freely provide for his family. Then, at the office, Jim's boss (coincidentally the father of Betty's date, Don) adds to Jim's 
discomfort by informing him that he has just bought Don a

car.

The boss then plays on Jim's fear of Betty's independence as he displays his own daughter's wedding album: "She was ready and quite willing to go away. I thought of all of the things I could have done for her and didn't do because I wanted her to do them for herself. Why did it seem so important? - When your daughter gets married, you'll understand." Jim, deeply affected, goes home and tells Betty he will buy the dress, though she refuses his help, announcing that she realizes it's about time that she did things for herself. "You're right, father," she says, "I can't stay tied to you and mother forever." She tells him that she has found a job, but she refuses to reveal where because, as she says, "You know what would happen. You'd all be down there hanging around." She turns to Jim with a final crushing comment: "Thanks for offering to buy me the dress, but double thanks for pushing me out of the nest and making me fly alone."

A week later, Jim finds Betty exhausted and asleep at her desk after a long day of work. He pleads with her to allow him to help her, and once again she refuses. Jim goes to bed and expresses his concern to Margaret: "Who knows what kind of people she's working for? She's just an innocent youngster. There's no telling what might happen to her." As he begins to fall asleep, there are indications that the ensuing dream is more of a nightmare. Jim is shot in close-up as he tosses and turns. The conventional harp music is jarring rather than soothing as a wavy dissolve transitions the scene from his bedroom to a Western saloon.

\section{Father Knows Best \\ Video: Father Knows Best}

As Jim pounds on his closet door, Margaret stands to the side while Betty rushes into the room to comfort her father. Betty's independence and the threat posed by her relationship with Don prompts Jim to dream that she is a skimpily clad dancer who must perform for men to earn money. His fear appears to be realized when Betty arrives home the next night and her coat falls open, revealing that she is wearing a short skirt, fishnet stockings, and highheeled shoes. Jim is concerned, but then he learns from his son Bud that Betty is working at Higson's Country Store. The next day, Jim visits her (confirming Betty's concern that if he knew where she worked, he would be hanging around). He 
sees that she is selling peaches in her skimpy outfit, which seems to placate him despite the fact that when Don coincidentally enters the store, Betty is so embarrassed that she hides and has Jim take her place.

In the end, Betty mysteriously earns enough commission to buy the dress. After she leaves on her date with Don, the doorbell rings and Kathy announces, "There's a man at the door with peaches. Cases of peaches." Despite Betty's attempts to "fly away," she remains dependent on her father, and Jim's patriarchal position is secured.

Jim's cinematic dream evokes the Western trope of the saloon madam who has a stable of "girls" who dance for men and are, in fact, prostitutes. It expresses what is not said in the narrative-that Betty's sexuality as well as her independence threaten to disrupt the family and thus must be contained. This imagery is not confined to the dream, but reappears in the narrative when it becomes apparent that Betty is, indeed, forced to use her sexuality to get the money she needs to buy a dress. In Jim's dream she is dressed rather conservatively in a long frilly dress with a high collar, but in the "realistic" narrative, she dresses provocatively to sell peaches. In both cases, she commodifies her body for money. The nightmare, by explicitly linking Betty's work to prostitution through cinematic codes, magnifies the tensions that are not resolved by the ending.

\section{Conclusion}

On the surface, it appears that the dream sequences in these sitcoms remain subordinate to the "realistic" narratives that resolve by affirming the ideology of domestic containment that marked their social context. They remain, on one hand, clearly marked by visual cues that separate them from the realistic narrative. It is along these lines that Caldwell refers to dream sequences as "altered states" that are "corralled" by the narrative, and Todorov suggests that there is often a tension between generic and cultural verisimilitude. Though dreams may be formally plausible, they are incompatible with the conventions of realistic representation associated with the domestic sitcom. On the narrative level, there is always a return to stability and an affirmation of domesticity that appears to negate the tensions expressed by the dream that threaten to disrupt the social order. Molly is content with being a housewife, and Joan realizes she is better off married; similarly, despite Donna Stone's dreams of becoming a movie star, she realizes that her family is more important. In Father Knows 
Best, Betty cannot be independent without the help of her father, and she does not keep working after she earns enough money for her dress.

But the interaction of dreams and narrative demonstrates that meaning is not contained by narrative closure nor is it defined by the "realism" of narrative verisimilitude. The pleasures these narratives offer come from the dreams' disruption of narrative form and content, rather than from the resolution of the tensions that the dream sequences introduce. As Steve Neale notes, it is those generic elements least compatible with regimes of cultural verisimilitude that offer the most pleasure. ${ }^{9}$ Here the dreams, motivated by character subjectivity or cinematic cues for subjectivity, are integrated into the narrative to give form to otherwise inchoate social tensions. In "Molly's Dreams," the dreams have no visual expression and are least disruptive; in "Dreams," they support the narrative representation of the rebellious character; and in "The Stones Go to Hollywood" and "Betty Earns a Formal," the dreams' visual excess alters both narrative form and content.

By expressing desires and anxieties that are expelled from the narrative, the dreams articulate characters' subjective realities, and in so doing, they blur generic and cultural verisimilitude, and the implausible becomes plausible. In all of these sitcoms, we see that Molly Berg, Joan Davis, and Donna Stone chafe at the ideological ties that bind them, just as Jim Anderson fears what might happen if those ties are broken. In the cases where dreams are visualized, the cinematic stylization also challenges the realism attributed to the domestic sitcom. The excess of the dream sequence disrupts narrative form and content to make visible what is repressed.

Dream sequences on television have continued to evolve. Sitcoms and dramas often feature dreams, whether to deepen character, provide exposition, or even to confuse viewers about what is "real." As televisual language has become more sophisticated in recent years, the elaborate coding that signifies the dream — the wavy dissolve, harp music, and shot of a character falling asleep is often elided altogether or used ironically. Moreover, as the fifties transitioned into the more liberal sixties, there was less need for dreams to contest the ideology of domestic containment. While dreams still expressed characters' fears and desires, they addressed a shifting social context where many women were able to give voice to what Betty Friedan called "the 
problem that has no name," and changing male roles were often represented as a crisis of masculinity.

In some cases, such as The Dick Van Dyke Show, dreams expressed fear of female "otherness," as in the classic "It May Look Like a Walnut" (1963) when Rob Petrie has a nightmare that his wife Laura is an alien. Notably, this episode did not use cinematic signifiers to indicate the dream, keeping viewers unsure of how to interpret the scenes. Or, in "The Bad Old Days" (1962), Rob's nightmare inverts the narrative, and he feels emasculated by his household duties, one of which includes wearing Laura's apron as he gives son Ritchie a bath. He dreams that he is Laura's "master" and orders her to do all of the household chores, but then he is lonely and has no one with whom to share his ample leisure time. He reawakens with a renewed commitment to companionate marriage. In this way, the dream resolves his tension and offers an alternative to the authoritative, patriarchal male of the fifties as he accepts more egalitarian gender roles.

Another oft-cited dream, Roseanne's "Sweet Dreams" (1989), uses the dream sequence to re-evoke the fifties ideology of domestic containment from a contemporary feminist perspective. Beset by demands from her family as she tries to take a shower, Roseanne dreams that two muscular men pamper her in an opulent spa. When her family appears one by one to interrupt her idyll, she murders each of them. She is put on trial and sentenced, but escapes when the dream transforms into a musical and the entire cast sings, "We love Roseanne." In the fifties sitcoms, the narrative resolutions reaffirm the patriarchal social order: when she awakes, the housewife embraces domesticity or the father continues to "know best." But Roseanne was a show that set out to destroy the ideology of the perfect wife and mother. ${ }^{10}$ When Roseanne finally wakes from her dream, her husband Dan jokes, "There's no place like home." Unlike the complacent Molly, Joan, or Donna, Roseanne utters, "Yeah, bull" as she strolls into the shower. There is no tidy narrative resolution. Roseanne is satisfied only in her dream, where her desires are fulfilled. These examples, while by no means exhaustive, illustrate the way that tensions around gender relations have remained a primary concern of the domestic sitcom, and dreams have continued to provide a means to negotiate them.

Comment on this article 


\section{About the Author}

Joanne Morreale is an Associate Professor in the Media and Screen Studies program at Northeastern University. Her scholarship includes work on political film, television history, and advertising. Her articles have appeared in Television and New Media, Feminist Media Studies, Journal of Film and Video, Journal of Consumer Culture, and Journal of film and Television. She is most recently the author of The Donna Reed Show (Wayne State University Press, 2012) and The Dick Van Dyke Show (Wayne State University Press, forthcoming).

\section{Endnotes}

1 See Lipsitz, Time Passages; Mellencamp, "Situation Comedy, Feminism and Freud"; May, Homeward Bound; Haralovich, "Sitcoms and Suburbs"; Coombs, The Way We Never Were; Spigel, Make Room for Television (1992), Welcome to the Dreamhouse (2001); Liebman, Living Room Lectures; Douglas, Where the Girls Are.

$\underline{2}$ Caldwell, Televisuality, 55-56.

$\underline{3}$ Mellencamp, "Situation Comedy, Feminism and Freud," 81.

4 Deming, "Locating the Televisual in Golden Age

Television," 137.

$\underline{5}$ Smith, Something on My Own, 199-202.

6 Sconce, "The Outer Limits of Television," 33.

I May, Homeward Bound, 207.

8 See Morreale, The Donna Reed Show.

9 Neale, "Questions of Genre," 158-59.

10 See Rowe, "Roseanne."

\section{Bibliography}

Burkhead, Cynthia. Dreams in American Television Narratives: From Dallas to Buffy. London: Bloomsbury, 2013.

Caldwell, John Thornton. Televisuality: Style, Crisis, and 
Authority in American Network Television. New York:

Rutgers Univ. Press, 1995.

Coombs, Stephanie. The Way We Never Were: American

Families and the Nostalgia Trap. New York: Basic Books, 1992.

Deming, Carol. "Locating the Televisual in Golden Age Television." In A Companion to Television, edited by Janet Wasko, 126-41. Oxford: Blackwell, 2010.

Douglas, Susan. Where the Girls Are: Growing Up Female with the Mass Media. New York: Random House, 1994.

Haralovich, Mary Beth. "Sitcoms and Suburbs: Positioning the Fifties Homemaker." Quarterly Review of Film and Television 11.1 (1989): 61-83.

doi:10.1080/10509208909361287

Leibman, Nina. Living Room Lectures: The Fifties Family in American Film and Television. Austin: Univ. of Texas Press, 1995.

Lipsitz, George. Time Passages: Collective Memory and American Popular Culture. Minnesota: Univ. of Minnesota Press, 1990.

May, Elaine Tyler. Homeward Bound: American Families in the Cold War Era. New York: Basic Books, 1988.

Mellencamp, Patricia. "Situation Comedy, Feminism and Freud: The Discourses of Gracie and Lucy." In Studies in Entertainment: Critical Approaches to Mass Culture, edited by Tania Modleski, 80-98. Madison: Univ. of Wisconsin Press, 1986.

Morreale, Joanne. The Donna Reed Show. Detroit: Wayne State Univ. Press, 2012.

Neale, Steve. "Questions of Genre." In Film and Theory: An Anthology, edited by Robert Stam and Toby Miller, 157-78. New York: Blackwell, 2000.

Rowe, Kathleen. "Roseanne: Unruly Woman as Domestic Goddess." Screen 31.4 (1990), 408-419.

doi:10.1093/screen/31.4.408

Sconce, Jeffrey. "The Outer Limits of Television." In The Revolution Wasn't Televised: Sixties Television and Social Conflict," edited by Lynn Spigel and Michael Curtin, 21-46. 
London: Routledge, 1997.

Smith, Glen D., Jr. Something on My Own: Gertrude Berg and American Broadcasting, 1929-56. Syracuse: Syracuse Univ. Press, 2007.

Spigel, Lynn. Make Room for Television: Television and the Family Ideal in Postwar America. Chicago: Univ. of Chicago Press, 1992.

Spigel, Lynn. Welcome to the Dreamhouse: Popular Media and Postwar Suburbs. Durham: Duke Univ. Press, 2001.

Todorov, Tzvetan. The Poetics of Prose. Ithaca: Cornell Univ. Press, 1977.

Published by the Dartmouth College Library. Copyright (C) Trustees of Dartmouth College. CC BY-NC 4.0 http://journals.dartmouth.edu/joems/ 